\title{
Puncture and cytology - sufficient for endoscopic diagnosis of pneumatosis cystoides intestinalis?
}

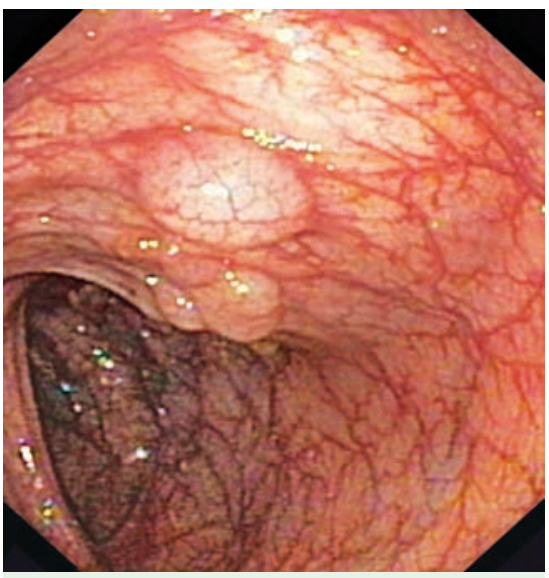

Fig. 1 Colonoscopy, case 1: there are several sessile, ball-shaped polyps covered with normal mucosa with an adequate vascular pattern.

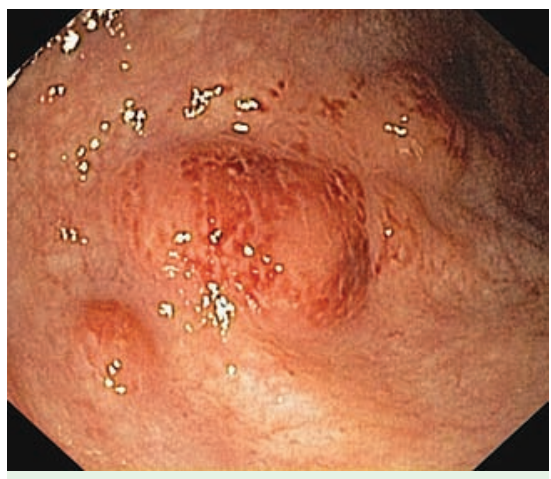

Fig. 2 Colonoscopy, case 2: small, sessile ball-shaped polyps covered with swollen, reddish mucosa.

Pneumatosis cystoides intestinalis (PCI), that is, presence of gas within the colonic wall, often has a polypoid appearance and can thus cause diagnostic uncertainty for the endoscopist [1-3].

Case 1. A 51-year-old man underwent colonoscopy for diarrhoea and slight hematochesia. Colonoscopy revealed small, sessile, ball-shaped polyps, which were clustered in streaks and covered with normal mucosa in the hepatic flexure region ( $\bullet$ Fig. 1$)$. The polyps disappeared on puncturing and suction with a needle ( $\bullet$ Video $\mathbf{1})$. The patient was symptom-free at that time and no pathology was found on an abdominal plain Xray film. (This case has been reported previously [4].)

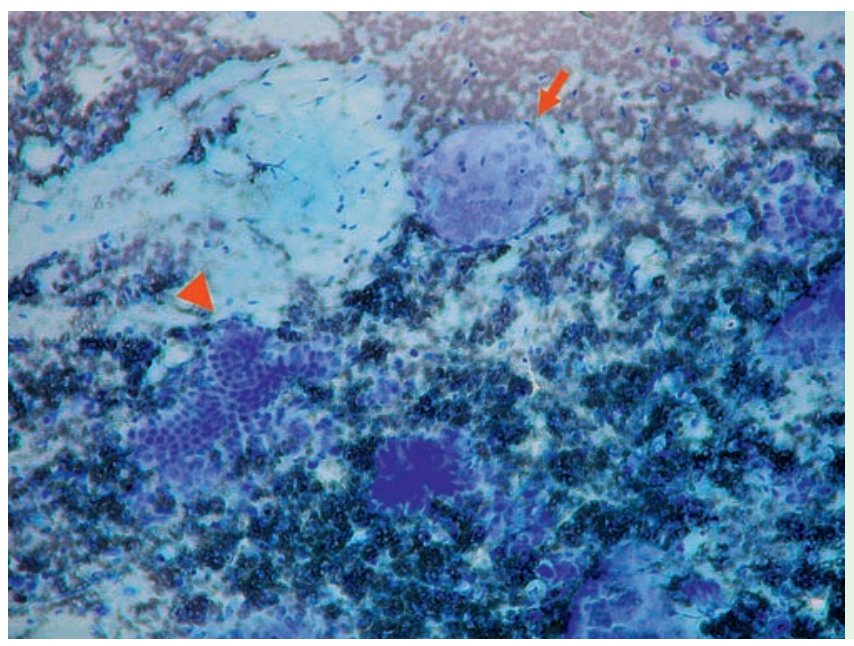

Fig. 3 Cytology, case 1. Multinucleated giant cell (arrow) and cluster of cylindrical colonic mucosal epithelial cells (arrowhead) with erythrocytes and mucus in the background (MayGrünwald-Giemsa staining, magnification $\times 100$ ).

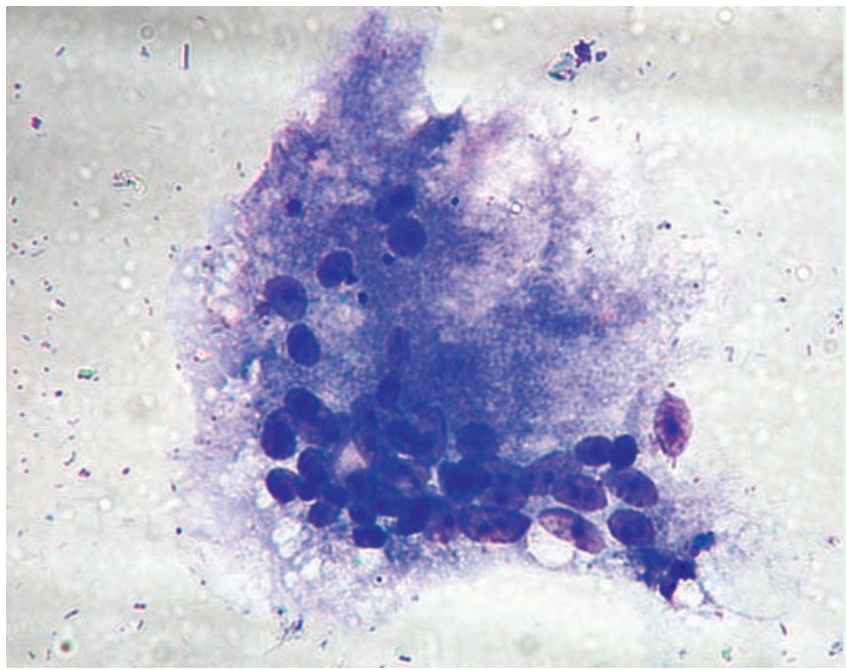

Fig. 4 Cytology, case 2. Multinucleated giant cell (May-GrünwaldGiemsa staining, magnification $\times 500$ ).

\section{Video 1}

Colonoscopy, case 1. Small, sessile, ballshaped polyps in the hepatic flexure region, quite firm on forceps palpation. The biopsy just unroofed the normal mucosa, and the polyps disappeared on puncture and suction with a needle.

Case 2. A 60-year-old obese man with a history of Clostridium difficile colitis was referred for lower endoscopy for a suspected perianal fistula. The patient was otherwise asymptomatic. Several small, sessile polyps were seen clustering in the splenic flexure region. Some of them were covered with swollen and reddish but otherwise normal mucosa ( $\bullet$ Fig. 2). An abdominal plain X-ray was normal; stool samples were negative for both standard culture and for $C$. difficile toxins $\mathrm{A}$ and $\mathrm{B}$. The aspirated material was sent for cytological examination. Numerous foreign body multinucleated giant cells on a background of normal mucosal epithelial cells were found in both cases ( $\bullet$ Fig. 3 and 4). To our knowledge these are the first two cases of diagnosis of PCI by fine needle aspiration cytology.

We conclude that a diagnosis of PCI suspected on endoscopy can be effectively confirmed by puncturing the pseudocysts and cytological examination of the aspirated material. Collapse of the pseudocysts on puncture and the presence of giant multinucleated cells in the cytologi- 
cal smears are supposed to be pathognomonic for this condition. The diagnosis can thus be easily confirmed and unnecessary treatment avoided.

\section{Acknowledgement}

$\nabla$

This study was supported by research project MZO 00179906 from the Ministry of Health of the Czech Republic.

Endoscopy_UCTN_Code_TTT_1AQ_2AC
J. Cyrany ${ }^{1}$, M. Kopáčová ${ }^{1}$, S. Rejchrt ${ }^{1}$, H. Hornychová2 ${ }^{2}$ M. Tomšová²,

V. Tyčová ${ }^{2}$, A. Ryška², J. Bureš ${ }^{1}$

1 2nd Department of Internal Medicine, Charles University in Prague, Faculty of Medicine and Teaching Hospital, Hradec Králové, Czech Republic

2 The Fingerland Department of Pathology, Charles University in Prague, Faculty of Medicine and Teaching Hospital, Hradec Králové, Czech Republic

\section{References}

1 Heng Y, Schuffler MD, Haggitt RC et al. Pneumatosis intestinalis: a review. Am J Gastroenterol 1995; 90: 1747 - 1758

2 Goldberg E, LaMont JT. Pneumatosis intestinalis. UpToDate [serial online] 2008 16.3. Available from http://www.uptodate.com Accessed: 12 November 2008

3 Höer J, Truong S, Virnich $N$ et al. Pneumatosis cystoides intestinalis: confirmation of diagnosis by endoscopic puncture. A review of pathogenesis, associated disease and therapy and a new theory of cyst formation. Endoscopy 1998; 30: $793-799$

4 Ryška A, Hornychová H, Tyčová V et al. Pneumatosis cystoides intestinalis - is it possible to diagnose it by fine-needle aspiration cytology? Diagn Cytopathol 2006; 34: $793-795$

Bibliography

DOI $10.1055 / \mathrm{s}-0029-1214667$

Endoscopy 2009; 41: E127-E128

(c) Georg Thieme Verlag KG Stuttgart · New York . ISSN 0013-726X

Corresponding author

\section{J. Cyrany, MD}

2nd Department of Internal Medicine

Charles University Teaching Hospital

Sokolská 581

50005 Hradec Králové

Czech Republic

Fax: +420-495-834785

jiri.cyrany@email.cz 